\title{
Determining oscillating system dynamic parameters of a near-bit junk pulper
}

\author{
Zainagalina Lyaisan Zulfarovna \\ Ufa State Petroleum Technological University, \\ Branch of the University in the City of Oktyabrsky, Russian \\ Federation \\ E-mail: zlz11@mail.ru \\ Gabdrakhimov Mavlitzyan Sagityanovich \\ Ufa State Petroleum Technological University, \\ Branch of the University in the City of Oktyabrsky, Russian \\ Federation \\ E-mail: zlz11@mail.ru
}

\author{
Suleimanov Rustem Iskhakovich \\ Ufa State Petroleum Technological University, \\ Branch of the University in the City of Oktyabrsky, Russian \\ Federation \\ E-mail: zlz11@mail.ru \\ Khabibullin Marat Yakhievich \\ Ufa State Petroleum Technological University, \\ Branch of the University in the City of Oktyabrsky, Russian \\ Federation \\ E-mail: zlz11@mail.ru
}

\begin{abstract}
Development of effective bottom hole cleaning equipment from junk is an effective way of enhancing productivity of drilling operations. The article describes the construction of the near-bit for enhancing bottom cleaning of vertical, slanting and horizontal wells from junk during drilling by a roller cutter. The description of a laboratory bench for a near-bit junk pulper is given. Experimental data of vibrodynamic properties of a near-bit sludge pulper oscillating system are represented in order to find the best parameters of the device elements. Laboratory tests showed that the amplitude of the drum oscillation depends on the shaft speed, spring force, and the drum inertia moment.
\end{abstract}

Keywords-horizontal wells, junk, near-bit device, junk drilling, spring force, vibration speed.

\section{I.}

\section{INTRODUCTION}

Nowadays horizontal drilling in well building and reconstruction is the best way of oil and gas exploration. Well drilling with slanting and horizontal parts increases annually. Not sufficient clearing from junk is the main reason of emergencies and difficulties during drilling horizontal wells. Cutting transport from high angle holes, especially, horizontal is rather complicated because flushing fluid in annulus is perpendicular to gravity forces, acting on junk, as well as due to eccentric position of the drill stem in the pit shaft. Due to these factors all accepted ways of cleaning stems during drilling horizontal wells are ineffective. During horizontal drilling all the junk goes downwards. For preventing junk sinking, atteration formation it is necessary for junk particles to be in suspended condition but not in drawn condition. But increasing mud density leads to well walls packing. It is known that the junk particles should be not bigger than 1-2 $\mathrm{mm}$ to be transported in suspended condition [1-12].

\section{MATERIALS AND METHODS}

Quality of well flushing out techniques and technology influences successful and safe process of well drilling. Speed of drilling, quality of a well, advance and endurance of the cutter, turbo-drill, and elements of drilling equipment depend on the quality of well cleaning from junk.

To improve bottom-hole cleaning from junk a near-bit junk pulper has been designed. The device is used in rotary drilling (rotor mode, bottom hole motor) above the cutter. This device crushes big particles of junk to size $2 \mathrm{~mm}$ and less.

Fig. 1 shows the scheme of junk pulper functioning in turbo-drilling. The main parts of the device are the case 2, with a screw conveyor 3 and a rotor 8 , a drum 5 . The turbodrill rotary shaft 10 and the drum connected by springs 13 , make an oscillatory system. During rotation of turbo drill the springs create torsional vibration of the drum that leads to breaking and screening of the junk. The screw conveyor and the rotor are inside the drum which has feeding and exiting canals 4,9 , holes 6 , knock out drum 7 . The upper part of the drum is ribbed 12, which touches the end face of the rotor. The device has a screw conveyor, which catches the junk and drives it to the rotor, which throws junk onto the knock out of the drum 7. Meanwhile the junk is broken and small particles of junk are screened through the drum and big particles are crashed by the end face of the rotor. 


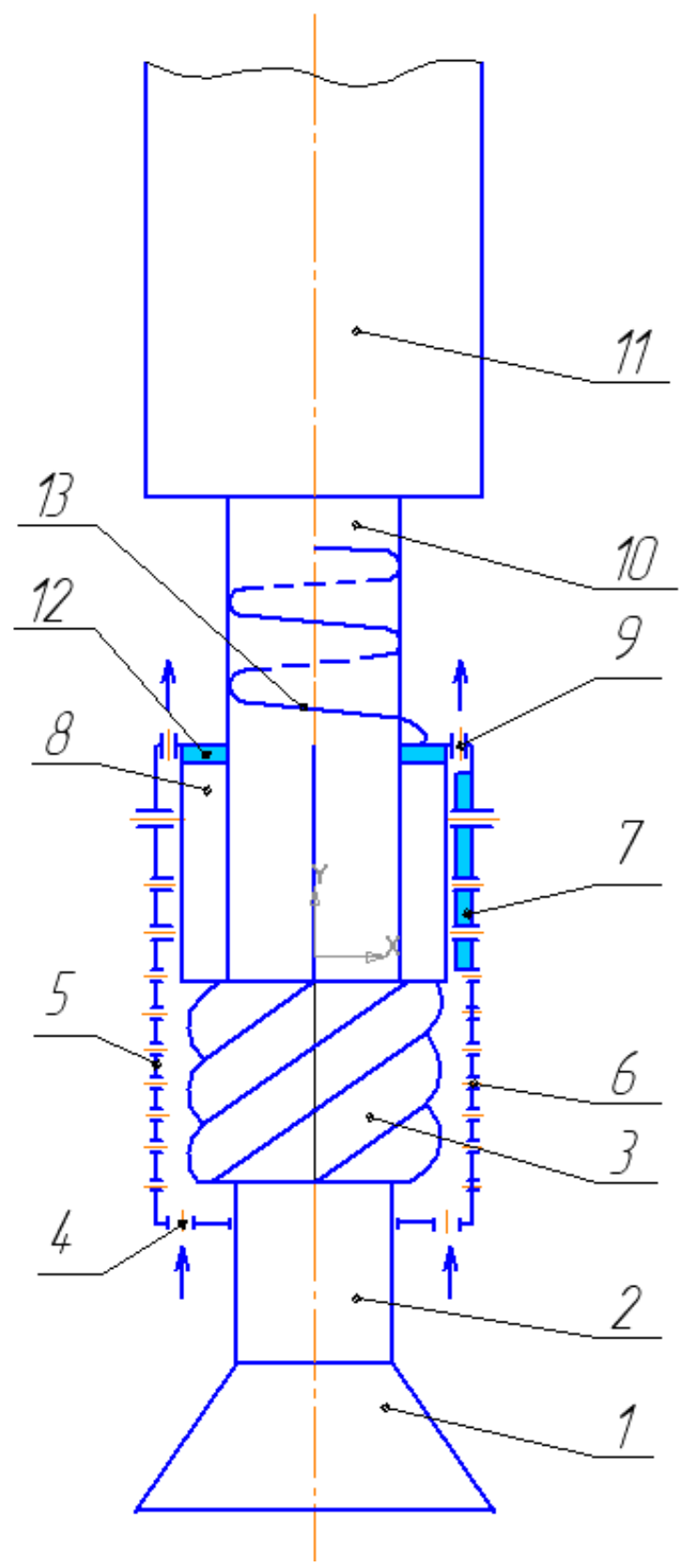

1 -drilling bit; 2 - case; 3 - screw conveyor; 4 - feeding holes; 5 - drum; 6 drum holes; 7 - knock out drum; 8 - rotor; 9 - exit canal; 10 - вал turbo drill shaft; 11 - turbo drill; 12 - drum ribbed surface; 13 - torsion spring

Fig. 1. Functional scheme of a near-bit junk pulper during turbo drilling

To test the near-bit junk pulper in laboratory conditions a laboratory bench was created at the oil-field machinery and equipment board of the Branch of FSBEE of HE of USOTU in Oktiabrski city (fig. 2).

Fig. 2 shows the laboratory bench for a near-bit junk pulper model studying. The bench is used to determine optimal parameters of oscillatory system of the near bit device: spring stiffness $c$, rotor speed $n$, drum inertia moment
$J_{d}$ and their influence on drum frequency and amplitude of oscillation. The bench consists of the frame 1, with the footing 2. The footings 2 hold the electric motor 3 , the speed regulator 4 and the drum 5 . The motor gives power to speed regulator 4 via junction box 6 . The drum is fixed to the shaft 7 , which is fixed to radial ball-joints 8 . The rotation from speed regulator 4 is transmitted via junction box 9 to the drum 5 . The drum is fixed to the shaft with the clearance by centralizers 11 . The drum 5 is connected with centralizers by springs 12 . A sensor is used to control rotation 10; a sensor 13 is used to measure vibration.

The bench functions in the following way. When the motor is switched on 3 the shaft 7 rotates together with the drum 5 . The drum rotates with the average speed of the shaft 7 and the speed is influenced by rotary vibrations created by oscillatory system of the near-bit junk pulper model.

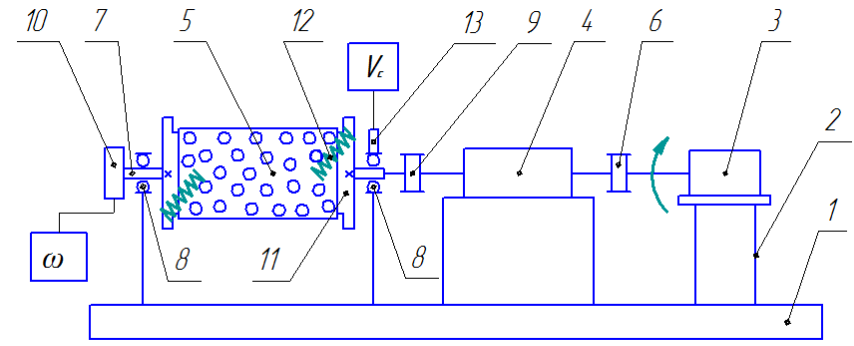

1 - frame, 2 -footing, 3 - electric motor, 4 - speed regulator, 5 - drum, 6, 9 junction box, 7 - shaft, 8 - radial ball joint, 10 - tachometer transmitter, 11 centralizers, 12 - springs, 13 - vibration sensor

Fig. 2. The bench scheme to study the near-bit junk pulper

The bench has control-measuring gauges: tachometer TEM1, vibration sensor "Diana-2M". Software "Atlant" and "Aurora-2000" are used to analyze the data. A highly sensitive gauge sensor is set in turns on the rotor footings, the frame; and the gauge fixes the information about the intensity and character of drum vibration.

\section{III.}

\section{RESULTS AND DISCUSSIONS}

The bench tests were conducted at different modes: change of shaft rotation speed $n$, spring tightness $c$, drum inertia moment $J_{d}$.

During planning the experiment root mean square value (RMS) of drum vibration speed was chosen as an optimization parameter. It depends on the following factors: number of shaft rotation, spring stiffness, and drum inertia moment. Fig. 3 and 4 show the results of drum vibration speed measuring. 


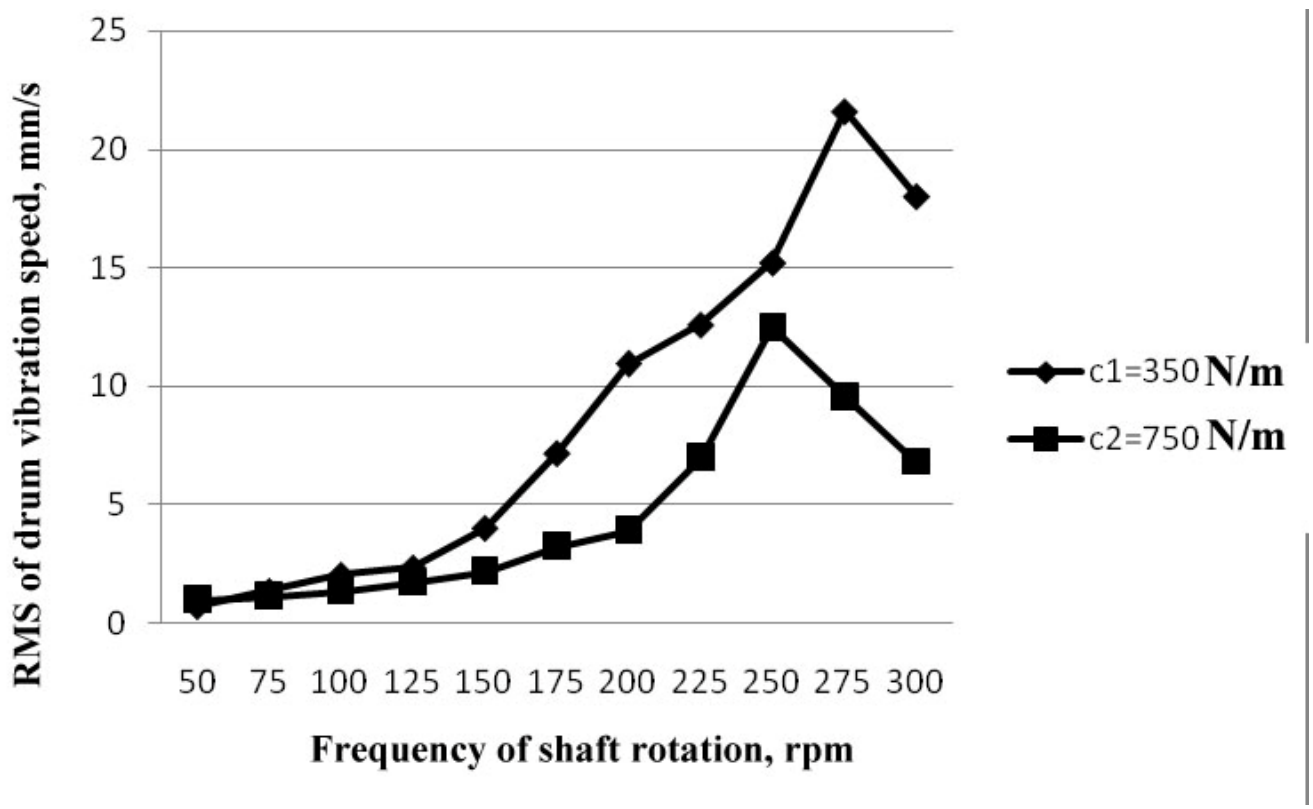

Fig. 3. Dependency graph of the root-mean-square value of the drum vibration speed on the shaft speed at the drum inertia moment $\mathrm{t} \mathrm{J}_{\mathrm{d}}=0,0036 \mathrm{~kg} \cdot \mathrm{m}^{2}$ and springs of different stiffness $\mathrm{c}$.

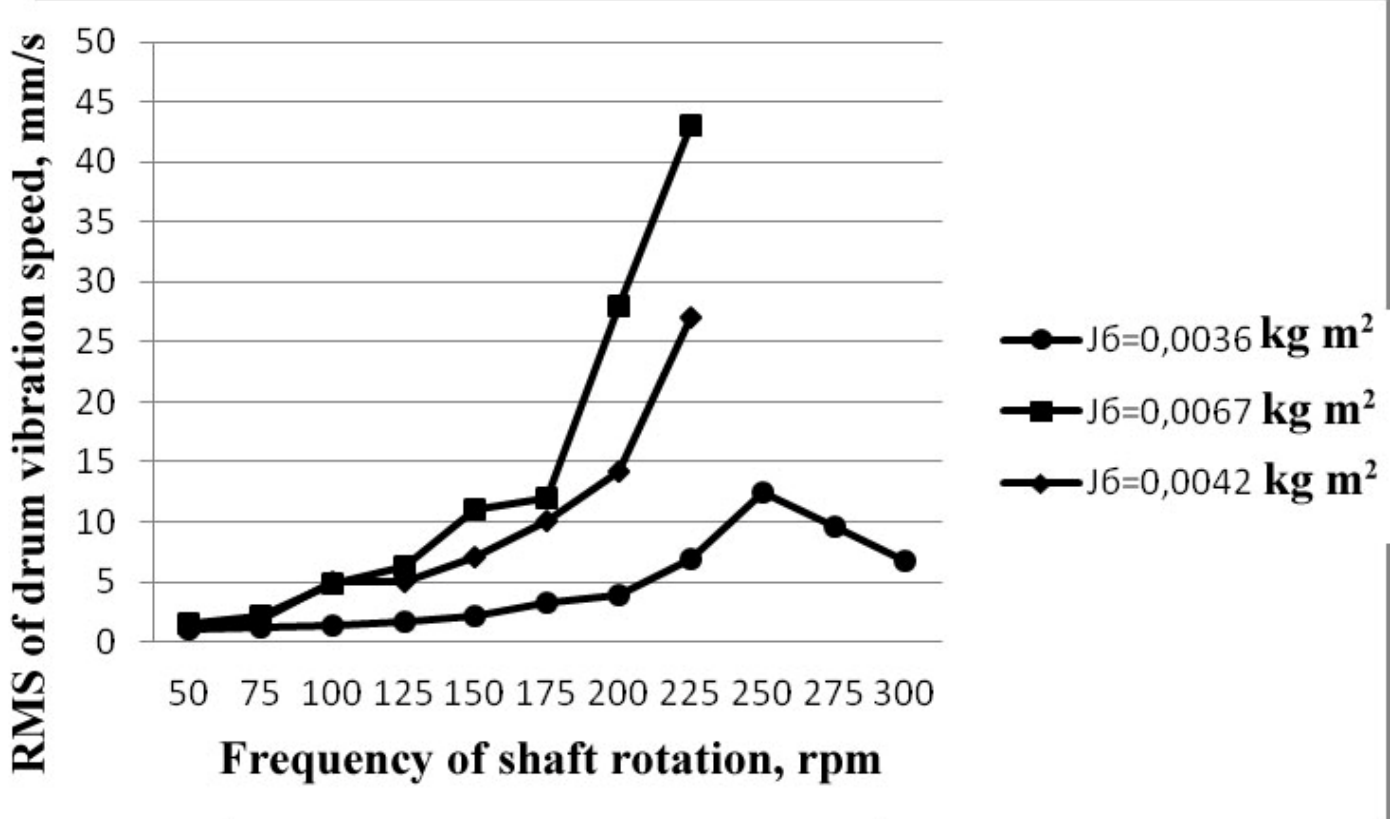

Fig. 4. Dependency graph of root-mean-square value of drum vibration speed on shaft speed $n$ with the spring stiffness $s=750 \mathrm{~N} / \mathrm{m}$ and different drum inertia moments $\mathrm{J}_{\mathrm{d}}$.

These graphs show that when the shaft speed increases to $200 \ldots 275 \mathrm{rot} / \mathrm{min}$ root-mean-square value of vibration speed increases (pictures 3, 4). At shaft speed 250-275 rot $/ \mathrm{min}$ resonance appears. The recommended shaft speed of the model is $50-200 \mathrm{rot} / \mathrm{min}$. When the spring stiffness increases RMS value decreases (picture 3 ). When drum inertia moment increases RMS value of vibration speed increases (fig. 4). The drum with inertia moment $\mathrm{J}_{\mathrm{d}}=0,0036 \mathrm{~kg} \cdot \mathrm{m}^{2}$ is the best.
Laboratory bench tests of the oscillating system of the near-bit junk pulper model prove the efficiency of the oscillating system of the near-bit junk pulper.

\section{IV.}

\section{CONCLUSION}

1. The near-bit junk pulper is suggested to improve the clearing of the bottom-hole zone of the well.

2. Experimental data of RMS value of vibration drum speed of the near-bit junk pulper dependence on the shaft 
speed are received for different drum inertia moments and spring stiffness. When shaft speed increases the drum vibration speed increases intensively at higher drum inertia values and less spring stiffness.

3. Positive results of laboratory tests prove the efficiency of the device.

\section{References}

[1] M.Ya. Habibullin, D.I. Sidorkin, Determination of tubing string vibration parameters under pulsed injection of fluids into the well, Proceedings, Vol. 3, pp. 27-32, 2016.

[2] V.V. Mukhametshin, "Eliminating uncertainties in solving bottom hole zone stimulation tasks," Bulletin of the Tomsk Polytechnic University. Geo Assets Engineering, vol. 328, no. 7, pp. 40-50, 2017.

[3] V.V. Mukhametshin and R.R. Kadyrov, "Influence of nanoadditives on mechanical and isolating properties of cement-based compositions," Nanotechnologies in Construction, vol. 9, no. 6, pp. 18-36, 2017. DOI: 10.15828/2075-8545-2017-9-6-18-36.

[4] R.T. Akhmetov, V.V. Mukhametshin, A.V. Andreev, and Sh.Kh. Sultanov, "Some Testing Results of Productive Strata Wettability Index Forecasting Technique," SOCAR Proceedings, no. 4, pp. 83-87, 2017. DOI: 10.5510/OGP20170400334.

[5] M.Y. Khabibullin, R.I. Suleimanov, D.I. Sidorkin, I.G. Arslanov, PARAMETERS OF DAMPING OF VIBRATIONS OF TUBING STRING IN THE OPERATION OF BOTTOMHOLE PULSE DEVICES. Chemical and Petroleum Engineering, Vol. 53, № 5-6, pp. 378-384, 2017.

[6] L.G. Akhmetov, A. Z. Ibatova, A. L. Popov, K. N. Yagafarova and M. A. Stavruk, Using on compressed gas vehicles combined injection of fuels Int. J. of Applied Engineering Research, Vol. 12 (24), pp. 1559298, 2017.

[7] N.Y. Golovina, L.G. Akhmetov, A.N. Vikharev, I.G. Arslanov, Analysis on compressor blading conditions of helicopter's gas-turbine engine working in polluted environment. International Journal of Applied Engineering Research, Vol. 12, № 3, pp. 293-296, 2017.

[8] W.C. Chin, Exact cuttings transport correlations developed for high angle wells. Offshore, p. 67, May 1990.

[9] T.I. Larsen, A.A. Pilehvari, J.J. Azar, Development of a new cutting transport model for high-angle wellbores including horizontal wells. SPEDC, p. 129, June 1997.

[10] D. Nguyen, S.S. Rahman, A three-layer hydraulic program for effective cuttings transport and hole cleaning in highly deviated and horizontal wells. SPEDE, p. 182, Sep. 1998.

[11] A.A. Pilehvari, J.J. Azar, S.A. Shirazi State of the ait cutting transport in horizontal wellbores. SPEDC, p. 196, Sep. 1999.

[12] G. Roussiaux, K. Ross, Cutting's flow meter takes guesswork out of hole cleaning. Petroleum Engineer International, p. 23, Sep. 1999. 